\title{
Verspraak onder hoogspanning
}

Citation for published version (APA):

Passchier, W. F. (1999). Verspraak onder hoogspanning. Maastricht University. https://doi.org/10.26481/spe.19991112wp

Document status and date:

Published: 12/11/1999

DOI:

10.26481/spe.19991112wp

Document Version:

Publisher's PDF, also known as Version of record

\section{Please check the document version of this publication:}

- A submitted manuscript is the version of the article upon submission and before peer-review. There can be important differences between the submitted version and the official published version of record.

People interested in the research are advised to contact the author for the final version of the publication, or visit the DOI to the publisher's website.

- The final author version and the galley proof are versions of the publication after peer review.

- The final published version features the final layout of the paper including the volume, issue and page numbers.

Link to publication

\footnotetext{
General rights rights.

- You may freely distribute the URL identifying the publication in the public portal. please follow below link for the End User Agreement:

www.umlib.nl/taverne-license

Take down policy

If you believe that this document breaches copyright please contact us at:

repository@maastrichtuniversity.nl

providing details and we will investigate your claim.
}

Copyright and moral rights for the publications made accessible in the public portal are retained by the authors and/or other copyright owners and it is a condition of accessing publications that users recognise and abide by the legal requirements associated with these

- Users may download and print one copy of any publication from the public portal for the purpose of private study or research.

- You may not further distribute the material or use it for any profit-making activity or commercial gain

If the publication is distributed under the terms of Article $25 \mathrm{fa}$ of the Dutch Copyright Act, indicated by the "Taverne" license above, 
Alle rechten voorbehouden. WF Passchier, Severij 1, 3155 BR Maasland 


\section{Verspraak onder hoogspanning}

Rede, witgesproken ter gelegenheid vam de a anwawinding van het ambt van bijzonder hooglerair 'Risico-analyse' bij de Faculteit der Gezondheidswetenschappen van de Universiteit Maastricht, op 12 november 1999, 16:30 mur door

WF Passchier 


\section{Coca-Cola}

Tn juni 1999 vertoonden kinderen in België verschijnselen van 1 buikpijn, misselijkheid en overgeven na het drinken van coca Cola. Enkele tientallen jongelui werden ter observatie in het ziekenhuis opgenomen. ${ }^{1)}$ Was hier sprake van vergiftiging? stelt $u$ die vraag an een technisch ingestelde milieugezondheidkundige, dan loopt deze een oorzaak-gevolgketen na: van de productie van de frisdrank stapsgewijs naar de gezondheidsklachten (figuur 1). Daarbij tracht hij de volgende vragen te beantwoorden:2)

- Welke stoffen in de drank of in de verpakking kunnen de ziekte. verschijnselen veroorzaken?

- In welke mate doen deze stoffen dat?

- Hoe groot was de blootstelling aan de stoffen

- Hoe groot is het risico op nare gevolgen na het drinken van verontreinigde colla en -in dit geval- hoe verhoudt die schatting zich tot het klachtenpatroon?

Op twee punten bleek het mis te zijn gegaan bij de colaproductie. ${ }^{3)}$ In de bottelarij in Antwerpen raakte het koolzuurgas dat voor de 'prik' zorgt, verontreinigd met zwavelkoolstof, zodat bij het openen van een flesje de 'lucht' je al tegemoet kwam. Daarnaast stonkem sommige blikjes dank zij een fenol-verbinding

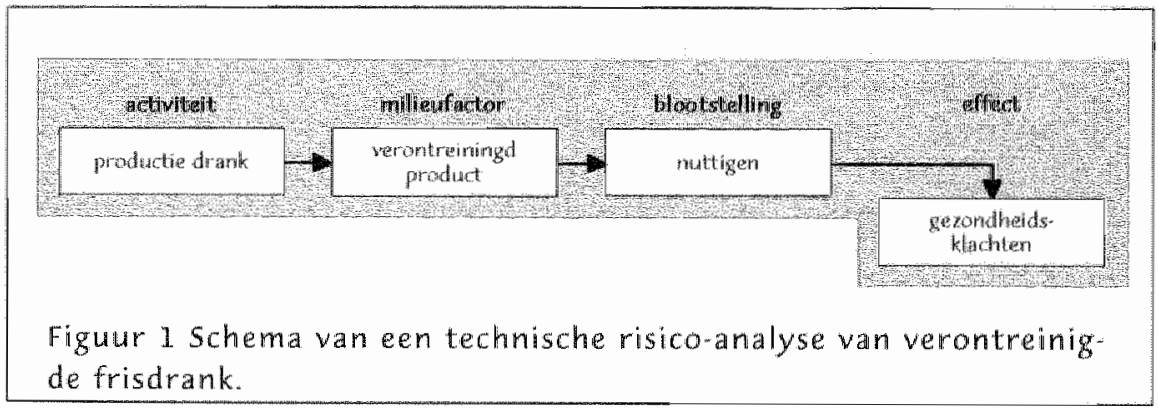

Coca-cola 
warmee pallets waren geimpregneerd. De conclusie van een risicoanalyse volgens figuur 1 was, aldus Cola-woordvoerders op 15 juni: geen blijvende gezondheidsproblemen.

Voor het nemen van een beslissing over het stilleggen van de productie, het terughalen van partijen frisdrank, het werbieden van de verkoop wan de frisdranken en de voorwa arden voor het opnieuw toelaten van het vocht tot de markt is zo"n technische risico-analyse niet voldoende. Dat blijkt als we nog een paar feiten van de Coca-Cola crisis de revue laten passeren. 1)

De eerste reactie van de Coca-Cola Company na de klachten van schoolkinderen in het Belgische Bornem was: Coke was en is veilig en wordt met de grootste mogelijke zorg voor het welzijn van de consument geproduceerd. Na enige aandrang van de schooldirecteur werd de 'stank'-partij wel teruggehaald. Het mogelijke verband tussen de klachten en het consumeren van de frisdrank, leidde tot een verbod van de Belgische overheid op de verkoop van alle frisdrank van het Amerikaanse bedrijf.

van een begeerde drank werd Coca-Cola plotsklaps eer ziekteverwekker. Allerlei mensen bleek het drinken van Coke of Fanta slecht te bekomen. Had het bedrijf het toxicologisch niet bij het juiste eind, of simuleerden de cola-liefhebbers? Op beide vragen luidt het antwoord ontkennend. Maar wel lijkt wast te staan dat de klachten ook een psychologische oorzaak hadden. Hoewel sommige kranten kopten dat de ziekte kennelijk 'tussen de oren' zat, makt dat de klachten van buikpijn, hoofdpijn, duizeligheid en overgeven niet minder reëel. 4),5),6)

6. Waarom een verhandeling over de risico's van mobiele telefonie ('verspraak') en die van de elektriciteitsvoorziening (hoogspanning") begonnen met cola? De Belgische cola-affaire illustreert wat de problemen zijn bij het beoordelen en beheersen van risico's. Het is niet alleen een kwestie wan toxicologie, stralings. hygiene of ongevalskansen. Een adequate risicobeoordeling is een stuk ingewikkelder. Mensen worden ook ziek door het feit dat bestuurders meer aan productiecijfers dan a an gezondheid van consumenten denken, of althans de indruk vestigen dat te doen. Coca-Cola had zich allereerst bezorgd kunnen tonen om het wel en wee van de zieke schoolkinderen. Het bedrijf had prompt de productie kunnen stilleggen totdat niet alleen de stinkende stofjes, maar ook de haperingen in het kwaliteitscontrolesysteem

Verspraak onder hoogrpanning, 12 november 1999 


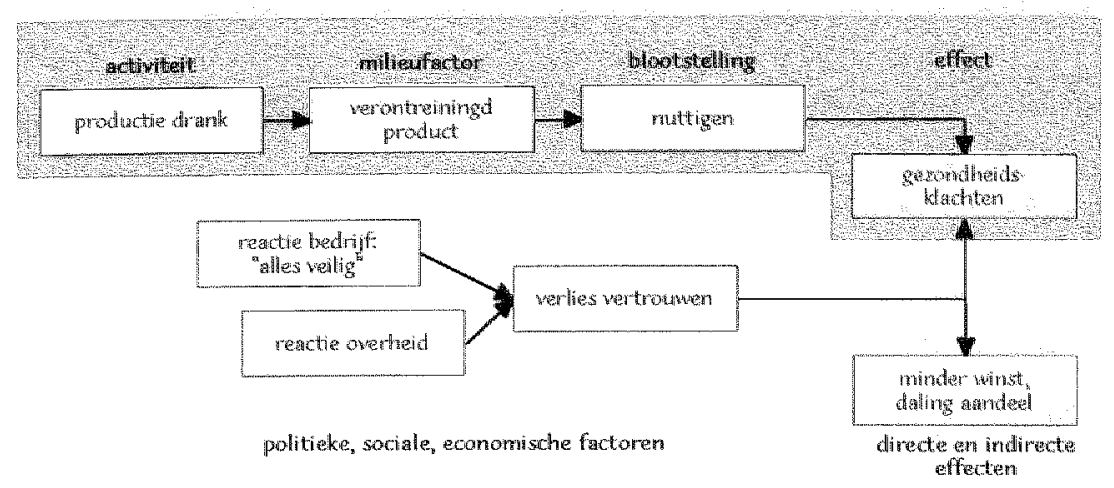

Figuur 2 Uitgebreide risico-analyse van verontreinigde frisdrank.

waren opgespoord. Dan was het aantal ziektegevallen mogelijk kleiner geweest, en had de overheid mogelijk niet ingegrepen.

De boodschap is: een misser in de productie kan leiden tot gezondheidsklachten, maar die gevolgen worden beinvloed - en in de cola-affaire versterkt - door het optreden van het bedrijf en de overheid en de reactie van consumenten daarop (figuur 2 ). Risicobeoordeling is beduidend meer en ingewikkelder dan het in kart brengen van de ziekmakende werking van stoffen of andere milieufactoren.7),8)

Het cola-incident had ook economische repercussies. De Coca-Cola Company verkocht in het tweede kwartaal van 19996 procent minder dan in de overeenkomstige periode een jaar eerder. En het bedrijf moest een grootscheepse campagne opzetten om de consument weer a an het eigen merk te binden. Elke Belg kreeg een gratis Coke en, bij het winnen van een promotieprijswraag een mobiele telefoon. 9),10) Dat brengt me bij het hoofdonderwerp van mijn verhaal: de risicobeoordeling van de elektriciteitsvoorziening en de mobiele telefonie. 


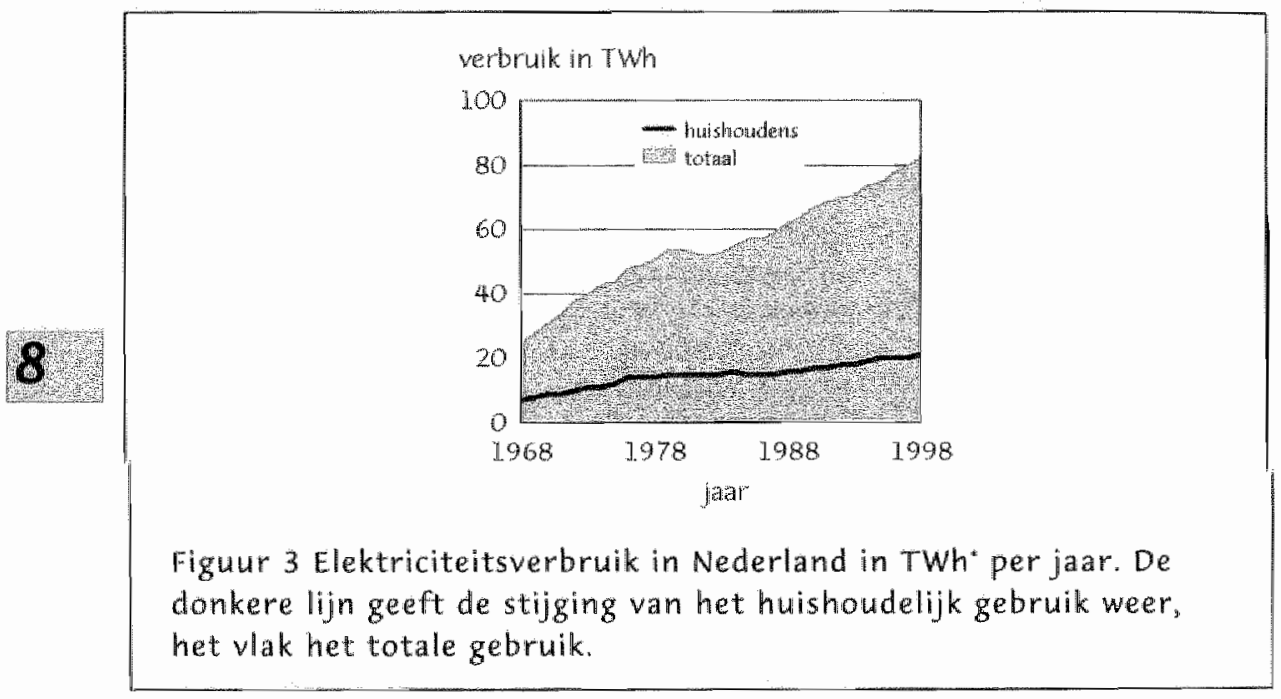

1 TWh staat voor 1 terawatt-uur en komt overeen met 1 miljard kilowatt-uur. 


\section{Extreem-laagfrequente, elektromagnetische velden}

$M$ et het in bedrijf nemen in 1886 van de eerste Nederlandse elektriciteitsfabriek te Kinderdijk was de openbare elektriciteitsvoorziening in ons land een feit. In onze huidige samenleving is het gebruik van elektriciteit niet meer weg te denken en het uitvallen van de stroom heeft ernstige gevolgen. Zo kostte een stroomuitval van verscheidene uren in New York in 1977 naar schatting 100 miljoen gulden aan directe en 600 miljoen gulden aan indirecte schade. ${ }^{11}$ ) In deze bedragen is de resulterende geboortegolf dan nog niet eens verwerkt.

Elektriciteit wordt opgewekt in energiecentrales en vandaar via bovengrondse hoogspanningslijnen van 380 en $110 \mathrm{kV}$ naar de verbruikerscentra getransporteerd. Daar wordt de hoogspanning in stappen omlaag getransformeerd en via een ondergronds kabelnet naar de stopcontacten van gebruiker geleid. De frequentie van de wisselspanning en -stroom van de elektriciteitsvoorziening bedraagt in Europa $50 \mathrm{en}$ in de VS $60 \mathrm{~Hz}$ en wordt extreem laagfrequent genoemd. Rond elektriciteitskabels en elektrische apparatuur heersen elektrische en magnetische velden, vaak tezamen aangeduid als elektromagnetische velden. De elektrische velden dringen niet in niet-geleidende materialen door, de magnetische wel.

In de afgelopen 30 jaar is het elektriciteitsverbruik ongeveer 4 maal zo groot geworden en per hoofd van de bevolking ruim 3 maal (figuur 3). Per huishouden blijft het elektriciteitsverbruik min of meer constant en schommelt al geruime tijd rond de 3 $M W^{*}$ per jaar. 12),13),14)

Ondanks de niet weg te denken rol van elektriciteit in onze samenleving groeide in de jaren ' 70 in de $V S$ het verzet tegen

1 MWh staat voor I megawatt-uur en komt overeen met 1000 kilowatt-uur. Extreem-laagfrequente, elektromagnetische velden 


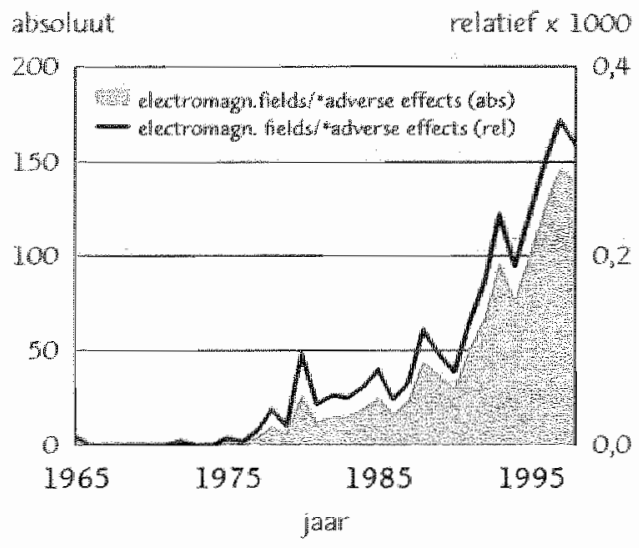

Figuur 4 Artikelen in het gegevensbestand Medline die zijn ingedeeld onder het trefwoord 'electromagnetic fields/*adverse effects'. Vlak ('abs'): antal artikelen, linker schaal; lijn ('rel"): antal artikelen gedeeld door het total a antal artikelen in Medline in het desbetreffende jaar, rechter schaal.

hoogspanningslijnen, in samenhang met de bezorgdheid over de gezondheidsgevolgen van de elektrische en magnetische velden rond die lijnen. Anno 1999 is het laatste woord over de gezondheidsrisico's van de elektriciteltsvoorziening nog niet gezegd. Ik will nu die risico's bespreken, met de nadruk op leukemie als mogelijk gezondheidseffect.

Wie zoekt in de medisch-wetenschappelijke literatuur onder 'elektromagnetische velden', ziet een gestadige toename van het aantal artikelen sinds 1975 (figuur 4). Dat geldt niet alleen in absolute zin, maar ook als rekening wordt gehouden met de drastische stijging van de productie van wetenschappelijke artikelen. In 1998 verschenen volgens het gegevensbestand Medline 140 artikelen over schadelijke gezondheidseffecten van elektro. magnetische velden. Dat komt overeen met ongeveer 3 per 10000 in het bestand opgenomen publicaties. Aangezien Medline niet alle gepubliceerde artikelen en rapporten omvat, zal het werkelijk aantal publicaties over elektromagnetische velden groter zijn. 
Wat gaf het startsein tot deze onderzoeksimspanning? In de eerste plaats de plannen voor de aanleg van 765 kilovolt-hoog. spanningslijnen tussen Canada en New York. $\left.{ }^{15}\right)_{3} 16$ ) De hoorzittingen over deze plannen brachten een scheiding wan de geesten teweeg, en wel tussen hen die menen dat de magnetische velden rond de lijnen de gezondheid niet schaden, en hen die menen dat dat wel het geval is of althans mogelijk is. Overigens waren de wetenschappelijke messen reeds eerder geslepen bij een antenneproject voor atoomonderzeeers waarbij magneetvelden van 10 hertz werden opgewekt. Zo'n militaire comnotatie is altijd goed voor extra bezorgdheid onder bevolking en controverses tussen deskundigen. ${ }^{17}$ )

voor het verloop van de discussie over extreem la agfrequente elektromagnetische velden is vooral onderzoek in Denver van cruciale betekenis geweest. De hoofdpersoom, de biologe en psy" chologe Nancy Wertheimer, trad in 1974 in het voetspoor van de Britse arts John Snow en trok in Denver van huis tot huis. Ze lokaliseerde de woningen waar kinderen met leukemie woonden of hadden geleefd. Daarbij viel het haar op dat bij die woningen vaak een elektriciteitspaal met een transformator stond. Het is een beeld dat we in Nederland niet kennen, daar hier in woonwijken de elektriciteit ondergronds wordt gedistribweerd. In de VS is het distributienet veelal bovengronds. Werthelimer wroeg zich af of de magneetvelden rond de stroomkabells niet de veroorzakers van de kinderleukemie waren. Vlak bij de transformatoren loopt immers de meeste stroom lopen en dat betekent dat daar het grootste magneetveld heerst; verder weg neemt het aantal stroomdraden en de stroom af, daar dan minder huizen bediend hoeven te worden. Samen met de natuurkundige Ed Leeper mat ze de sterkte van de magneetvelden buiten op straat; de resultaten leken haar veronderstellingen te bevestigen. Alle kosten woor het onderzoek kwamen uit de beurs van Wertheimer zelf. 15)

"John Snow (1813-1858) was de eerste arts die van anesthesie zijn beroep makte. Hij is vooral bekend geworden door an te tonen dat verontreinigd water de oorzaak was van cholera. In de woningen met cholera gebruikten de bewoners water afkomstig vam een bepalde waterpomp. In 1854 liet hij de zwengel van die waterpomp op de kruising van Broad Street en Cambridge Street in Londen verwijderen en makte zo een einde a an de cholera-epidemie in de omgeving.

Extreem-laagfrequente, elektromagnetische welden 
In 1979 publiceerden Wertheimer en Leeper hun bevindingen in een wetenschappelijk tijdschrift. ${ }^{18}$ ) Ze stelden dat de resultaten wezen op een verband tussen wire codes en kinderleukemie. "Wire code" was term die ze gebruikten voor configuraties van elektriciteitsdraden. De beide onderzoekers beschouwden de wire code als een mat voor het magneetveld.

Het artikel gaf het startsein tot een polemiek, zowel in wetenschappelijke kring als daarbuiten. In het begin van de jaren ' 80 kreeg Wertheimer nogal wat kritiek te verduren. De uitkomst van onderzoek door 'erkende' epidemiologen bleek echter in overeenstemming met haar resultaten. Maar ook bleek dat het "echte" magneetveld in de woning nauwelijks samenhang met kinderleukemie vertoonde, in tegenstelling tot de wire code. ${ }^{19)}$ Recent onderzoek geeft overigens op dit punt tegenstrijdige resulta. ten.20), 21)

Ook al levert epidemiologisch onderzoek enige aanwijzingen voor een verband tussen magnetische velden en leukemie, dan wil dat niet zonder meer zeggen dat het magneetveld de ziekte veroorzaakt. Theoretische beschouwingen en onderzoek met proefdieren en weefselcellen kan het vermoeden versterken dat magneetvelden echt de boosdoeners zijn. Die beschouwingen en dat onderzoek leverden in dit geval vooral wetenschappelijke tegenstellingen op. De meer fysisch georiënteerde wetenschappers concludeerden op basis van de elektromagnetische theorie, dat magneetvelden geen kanker kunnen veroorzaken. ${ }^{22)}$ Biologen bleven met onwerklaarde mar ook vaak niet te reproduceren effecten van extreem-laagfrequente velden in hun magg zitten. ${ }^{23}$ )

Om in dit soort situatie uitkomst te bieden, roept men commissies van deskundigen uit uiteenlopende disciplines bijeen. Men hoopt dat het verzamelde intellect het wetenschappelijk kaf van het dito koren kan scheiden en dat kermis en ervaring garant sta an voor het goed wegen van onzekerheden en het overbruggen van kennislacunes veroorzaakt door ontbrekend feitenmateriaal. In 1992 formuleerde een commissie van de Gezondheidsraad haar conclusie aldus:24)

Concreet gezegd, meent de commissie dat het verrichte onderzock onvoldoende consistente aanwijzingen levert om te kunmen stellen dat bloot. stelling an [extreem-laagfrequente elektromagnetische] velden afkomstig van het elektriciteitsdistributiesysteem [...] het ontstaan of de 
ontwikkeling van bepalde kwaadaardige aandoeningen beinvloedt [...] . De commissie wijst er op dat in enkele epidemiologische onderzoeken in de Verenigde Staten een relatie is gerapporteerd tussen de configuratie van de bovengrondse draden van het elektriciteitsdistributiesysteem (de 'wire code') en het vóorkomen van leukemie bij kinderen. Deze relatie is volgens de commissie echter onvoldoende aamleiding woor het a annemen van een oorzakelijk verband tussen blootstelling an [extreem-laag. frequente elektromagnetische] velden en het vórkomen van leukemie (of andere vormen van kanker), omdat een relatie met de gemeten sterkte van de [elektromagnetische] velden niet is gevonden.

De commissie maakt dus wel melding over het verband tussen wire codes en leukemie, maar meent dat de velden van de elektriciteitsvoorziening daarvan niet de oorzaak zijn.

In $1997 \mathrm{kwam}$ een commissie van de Academie van Wetenschappen in de vs tot de conclusie:25)

[...] dat er thans geen bewijs is voor de stelling dat deze [elektrische en magnetische] velden [van het elektriciteitsnet] een gevaar vormen voor de gezondheid. In het bijzonder is geen sluitend en consistent wetenschappelijk bewijs dat elektrische en magnetische velden in de woonomgeving kanker veroorzaken [....] In verscheidene onderzoeken wordt een samenhang tussen configuraties van elektriciteitslijnen (zogeheten 'wire codes' [...]) en kinderleukemie gevonden, hoewel de factor die verant. woordelijk is voor dat statistische verband niet is opgespoord. Gemeten warden van het magneetveld (na het optreden van de ziekte) blijken echter geen relatie met kinderleukemie te vertonen."

[...] the conclusion of the committee is that the current body of evidence does not show that exposure to the these [power-frequency electric and magnetic] fields presents a human health hazard. Specifically no conclusive and consistent evidence shows that exposures to residential electric and magnetic fields produce cancer, adverse neurobehavioral effects, or reproductive and developmental effects. [...] An association between residential wiring configurations (called wire codes [...]) and childhood leukemia persists in multiple studies, although the causative factor responsible for that statistical association has not been identified. No evidence links contemporary measurements of magnetic field levels to childhood leukemia.

Entreem-laagfrequente, elektromagnetische velden 
Deze conclusie lijkt als twee druppels water op die van Gezondheidsraad. Vijf jaar later zijn de theoretici kennelijk nog geen stap verder, heeft het laboratoriumonderzoek geen licht in de elektrische duisternis verschaft en ondersteunt nieuw epidemiologisch onderzoek de raadselachtige bevindingen van Wertheimer zonder magneetvelden als boosdoener aan te wijzen.

In 1992 nam het Amerikaanse Congres een wet aan waarin het National Institute for Environmental Health Sciences (NIEHS) opdracht kreeg onderzoek uit te zetten en mede op basis daarvan na vijf jaar te rapporteren over de risico's van de velden van de elektriciteitsvoorziening voor de gezondheid. Dit mandaat werd later met een jaar verlengd. In juni van dit jaar (1999) presenteerde NIEHS-directeur olden zijn eindrapport. Hij concludeerde: 26$)$

Het wetenschappelijk bewijs voor een schadelijke inwloed van blootstelling aan extreem laagfrequente elektromagnetische velden op de gezondheid is zwak. De sterkste aanwijzingen zijn afkomstig wit onderzoek onder bevolkingsgroepen naar het verband met kinderleukemie en nar het verband met chronische lymfatische leukemie onder beroepsmatig blootgestelden. [...] Het NIEHS concludeert dat blootstelling a an extreemlaagfrequente elektromagnetische velden niet als volstrekt veilig kan worden beschouwd vanwege de zwakke wetenschappelijke aanwijzingen dat die blootstelling tot leukemie kan leiden."

In vergelijking met de conclusies van de Gezondheidsraad en de Amerikaamse Academie van Wetenschappen is er sprake van een verschuiving: in plaats van 'er is geen aanwijzing dat er iets aan de hand is' stelt thet NIEHS-rapport dat 'er iets aan de hand lijkt te zijn, zij het niet vreselijk erg'.

Een risico-analyse van de elektriciteitswoorziening dient niet alleen de blootstelling a an extreem-laagfrequente elektromagne. tische velden in ogenschouw te nemen. Waardedaling van woning

The scientific evidence suggesting that ELF-EMF exposures pose any health risk is weak. The strongest evidence for health effects comes from associations observed in human populations with two forms of cancer: childhood leukemia and chronic lymphocytic leukemia in occupationally exposed adults. (...) The NIEHS concludes that ELF-EMF exposure cannot be recognized as entirely safe because of weak scientific evidence that exposure may pose a leukemia hazard. 


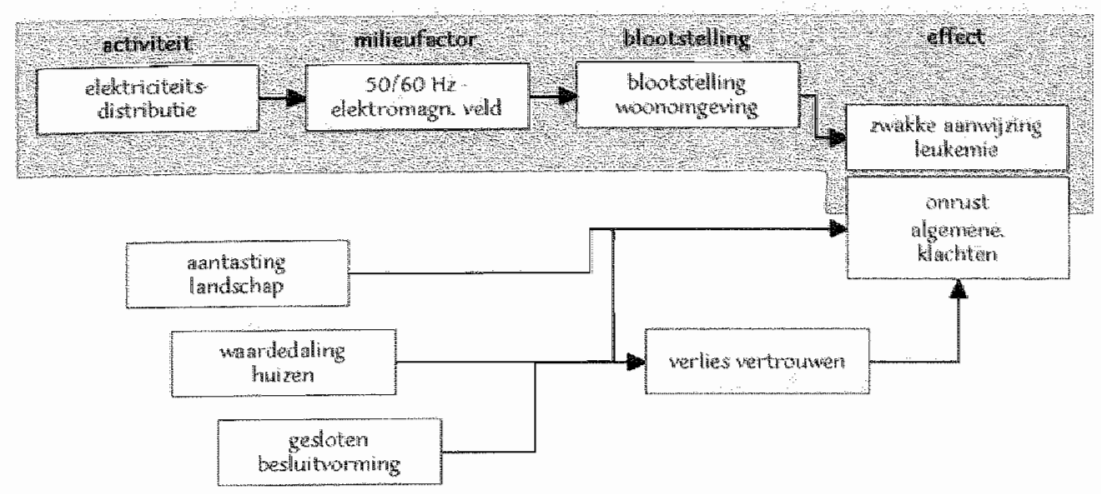

politieke, socialle, ecomorntsche fantoren

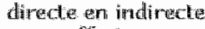
effecter

Figum 5 Risico-analyse van de elektriciteitsvoorziening.

door de aanleg van een hoogspanningslijn in de nabijheid kan ernstige financiële en sociale gevolgen voor de bewoners hebben en heeft in de VS ook tot, overigens vruchteloze, claims geleid. Via stress - bijvoorbeeld door de financiële onmogelijkheid te verhuizen - kan de gezondheid te lijden krijgen. Ook de aantasting van het natuurlijke landschap door hoogspanningslijnen ('horizonvervuiling') kan van belang zijn. 27),28) Mede door de voor burgers valk ondoorzichtige besluitvorming speelt verlies aan vertrouwen een rol. In figuur 5 zijn de bevindingen over de invloed van de elektriciteitsvoorziening op de gezondheid samengevat. Bij een complete risicobeoordeling horen ook alternatieven te worden betrokken. Het omleiden van hoogspanningslijnen is niet gratis en kosten komen uiteindelijk bij de elektriciteitsconsument terecht.

Het afwegen van de diverse altermatieven, onderling en tegen de voordelen van gebruik van elektriciteit, is onderdeel van een beleidsproces. Ten behoeve van dat proces is het gewenst de resultaten van de risico analyse overzichtelijk samen te vatten. In figuur 6 doe ik daartoe een poging, warbij ik me vooral richt op de elektromagnetische velden wan de elektriciteitsdistributie. Met balletjes geef ik de bewijskracht van het epidemiologisch onderzoek en van het laboratoriumonderzoek, het a antal getroffenen,

Extreem-Laagfrequente, elektromagnetische vedden 


\begin{tabular}{|c|c|c|c|c|c|}
\hline & $\begin{array}{c}\text { bewis } \\
\text { epddemiologe }\end{array}$ & $\begin{array}{l}\text { kennic } \\
\text { mechanisme }\end{array}$ & $\begin{array}{c}\text { awntal } \\
\text { getroftenen }\end{array}$ & $\begin{array}{c}\text { onzekphed } \\
\text { gevolger }\end{array}$ & $\begin{array}{l}\text { mogellhheld } \\
\text { maatregeten }\end{array}$ \\
\hline $\begin{array}{l}\text { Ganker } \\
\text { woning }\end{array}$ & 62 & 60 & 60 & 600 & 60 \\
\hline $\begin{array}{l}\text { kanker el. } \\
\text { apparatuur }\end{array}$ & 80 & $6 \times 3$ & (6) & $0 \times$ & 50 \\
\hline $\begin{array}{l}\text { arclere } \\
\text { affecten }\end{array}$ & 00 & 00 & & & \\
\hline 86 & $\begin{array}{l}\text { chaos } \\
\text { begerkt } \\
\text { poldoende }\end{array}$ & $\begin{array}{l}\text { chaos } \\
\text { beperkt } \\
\text { goed }\end{array}$ & $\begin{array}{l}\text { enkeling } \\
\text { groepen } \\
\text { velen }\end{array}$ & $\begin{array}{l}\text { gering } \\
\text { aanzientilk } \\
\text { groot }\end{array}$ & $\begin{array}{l}\text { senvolig } \\
\text { lastg } \\
\text { anmogetils }\end{array}$ \\
\hline
\end{tabular}

Figuur 6 Karakteristiek van de risico's verbonden met de elektriciteitsvoorziening. In de rij "andere effecten' zijn de laatste drie kolommen niet ingevuld, daar er aanwijzingen zijn dat deze effecten niet optreden.

de mate van onzekerheid over de omvang van de gevolgen en de mogelijkheid van matregelen aan.

$u$ verbaast zich mogelijk over de conclusie dat ook bij gebrekkige kennis de mate van onzekerheid toch gering is. Dat komt omdat uit het onderzoek tot nu toe wel kan worden afgeleid dat de elektriciteitsvoorziening niet in heel sterke mate bijdraagt aan de ziektelast van de bevolking. Zo heeft koops onlangs ten behoeve van een commissie van de Gezondheidsraad becijferd dat als elektriciteit kinderleukemie veroorzaakt in het ongunstige geval het in Nederland gaat om één extra geval van kinderleukemie in 3 jaar ten gevolge van de elektriciteitsdistributie. Ter vergelliking: per jaar treden ruim 100 gevallen van leukemie in de leeftijdsgroep van 0 tot 15 jaar op en overlijden ongeveer 40 kinderen aan deze ziekte." Hoe ernstig elk geval van leukemie ook is, er is geen sprake van een grootschalige bedreiging van de gezondheid van mens en milieu. Op de noodzaak van maatregelen ga ik straks in.

Persoonlijke mededeling van Drs FBJ Koops, KEMA NV, Arnhem, september 1999. 


\section{Mobiele telefonie}

1 ijkt de zorg over gevolgen van hoogspanningslijnen voor de Lezondheid wat te zijn weggeëbd, die over de gevolgen van de draadloze 'verspraak' is groeiende. Ik begin dit deel van mijn betoog met twee berichten die de maatschappelijke "hoogspanning' rondom mobiele telefonie illustreren. Allereerst het verhaal van de olieman die achter de tralies verdween:29)

Op 21 juli 1999 veroordeelde een rechter in Manchester Nell Whitehouse tot één jaar gevangenisstraf. De 28 -jarige werknemer in de olie-industrie had geweigerd in een vliegtuig van British Airways zijn mobiele telefoon uit te zetten. De rechter stelde dat Whitehouse het leven van zijn 90 medepassagiers en van de bemanning in gevaar had gebracht. Ook al makte hij geen gebruik van zijn toestel, toch hadden de navigatiesystemen van de Boeing 737 ontregeld kunnen raken. De Internetkrant warin dit bericht verscheen, vroeg de lezers om hum mening. Van de resulterende selecte steekproef van 3600 Internet-surfers meende 80 procent dat Whitehouse kreeg wat hij verdiende. Een enkele lezer stelde additionele stokslagen voor. De andere 20 procent vond de straf te zwaar en achtte de overtreding minder ernstig dan geweld tijdens de vlucht.

En in NRC-Handelsblad van 21 september 1999 stelt Anne Fleming dat de mobiele telefoon een bedreiging vormt voor de geestelijke volksgezondheid: ${ }^{30}$ )

Er is wél lets aan de hand: de mobiele telefoon heeft ons gedrag in het openbaar volkomen veranderd. [...] De techniek is alle etiquette, ieder gevoel voor sociale omgangsvormen dat wij eventueel bezaten, voorbijgesneld, zodat wij geen spier meer vertrekken wanneer wij mensen door hun mobiele telefoon hun hart horen witstorten, horen schelden of kirren. Wij zijn een volk van dwangmatige communicatorem geworden, van non-stop-kletsmeiers, die uiting geven aan onze allerpersoonlijkste 

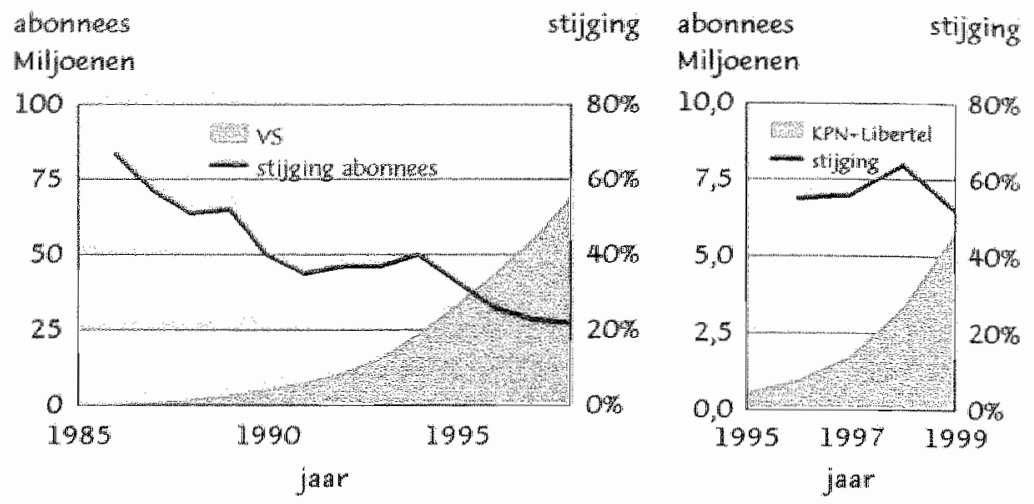

Figuur 7 Abonnees van draadloze-telecommunicatiediensten in de $V^{311}$ en van KPN" en Libertel" in Nederland. Vlak: totaal aantal; lijn: procentuele stijging.

gedachten in de alleropenbaarste ruimten - in de hal van een vliegveld, in een restaurant of midden op straat.

Voor het verbeteren van het onverbeterlijke heb ik geen recept. Ik wil met $u$ de vraag bespreken: word je van dat gebel ook nog ziek, in het bijzonder door de elektromagnetische straling die erwoor zorgt dat $u$ en ik zonder snoertje wanaf een willekeurige locatie met elkaar kunnen spreken. Dat de mobiele telefoon in hoog tempo is opgerukt in het leven van alledag illustreren de grafieken in figuur 7.

Een mobiel telefoon-netwerk bestaat uit een verzameling antenne-installaties die de ene mobiele beller met de andere dan wel met het vaste telefoonnetwerk verbinden. Het contact komt tot stand door elektromagnetische straling in het gebied rond 1 gigahertz, dat wil zeggen frequenties meer dan 100 miljoen maal groter dan de frequentie van de elektriciteitsvoorzlening. Doordat een mobiele telefoon die 'aan' staat, continu contact zoekt met de dichtstbijzijnde antenne is de beller steeds bereikbaar. Dit

- Persoonlijke mededeling van de heer K Zijlstra van KPN Telecom, Den Haag.

"Persberichten Libertel op Internet: http://www libertel. nl geraadpleegd 28-09. 1999. 


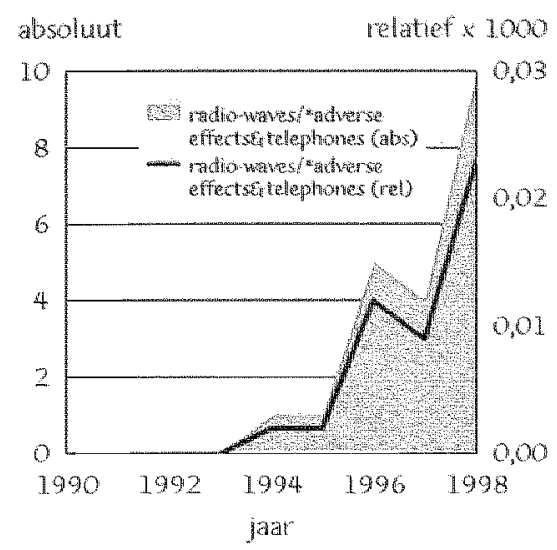

Figuur 8 Artikelen in het gegevensbestand Medline die zowel zijn ingedeeld onder het trefwoord 'radiowaves/*adverse effects' als onder het trefwoord "telephones". Wlak (abs): a antal artikelem, linker schaal; lijn (rel): antal artikelen gedeeld door het total a antal artikelen in Medline in het desbetreffende jaar, rechter schaal.

systeem brengt overigens, nog weinig aandacht krijgende, privacy-problemen met zich mee. De gangen van de mobiele beller kunnen immers voortdurend worden nagegaan en Orwell's "Big Brother'tijdperk is weer een stapje naderbij."

luit figuur 8 blijkt dat de wetenschappelijke belangstelling voor telefoons en gezondheid van recente datum is. Medline bevat voor het jaar 199810 artikelen over de gezondheidseffecten van mobiele telefonie, wat overeenkomt met 2 van elke 100000 referenties die in dat jaar aan het gegevensbestand werden toegevoegd.

$\mathrm{Nu}$ is de aandacht voor elektromagnetische straling in het megahertz-en het gigahertz-bereik"* wel van oudere datum. In verband met bijvoorbeeld de toepassing van radar, van microgalf.

- De Federal Communications Commission in de WS heeft onlangs het gebruik van mobiele telefoons in combinatie met het satelliet positie-systeem (Global Positioning System of GPS) gaedgekeurd. De 112-brigade (in de VS 911) zou dan sneller ter plaatse kumnen zijn. ${ }^{32}$ ?

" $1 \mathrm{MHz}$ staat voor 1 megahertz en komt overeen met 1 miljoen hertz. $1 \mathrm{GHz}$ staat voor I gigahertz en komt overeen met I miljard hertz. 
ovens en van radiocommunicatie zijn de effecten wan radarstraling, microgolven en radiogolven op de gezondheid onderzocht. Overigens is die wetenschappelijke activiteit veelal gestimuleerd door alarmerende berichten in de media, bijvoorbeeld over vrouwen die miswormde baby's kregen door microgolfovens en politiemannen met testiskanker door radarpistolen voor snelheidscontrole. Het onderzoek naar mobiele telefoons schart zich nu in de rij. Zo zei Roger Coghill, die campagne voert voor war. schuwingstickers op mobieltjes, in april 1999 voor de BBC.33)

Ik zie niet in hoe bij normaal gebruik mobiele telefoons een gevaar voor de gezondheid vormen. Maar sommige mensen bellen 20 tot 30 miruten per dag of meer. Er is ruimschoots wetenschappelijk materiaal voorhanden dat a angeeft dat dat een gevar is voor de gezondheid. Mijn advies is om niet in paniek te raken en de telefoon gewoon te gebruiken, maar gesprekken te beperken tot ongeveer 5 minuten per dag.

Een betere manier om paniek te zaaien kan je nauwelijks bedenken.

Eerder meldde de BBC al dat Stephen Corney, een 39 jaar oude technicus bij British Telecom, zijn werkgever aansprakelijk stelde voor geheugenverlies. De inmiddels arbeidsongeschikte Corney stelde dat na het gebruik van een digitale mobiele telefoon het voelde alsof een stalen band zijn hoofd afklemde en hij knock-out geslagen was. Hij was jarenlang een frequente mobiele beller en voerde vaak gesprekken van meer dam anderhalf uur. ${ }^{34}$ )

Het weerwoord van de wetenschap na dit soort berichten was: 20 'veel onduidelijk', 'onwaarschijnlijk", 'geen bewijs', en dergelijke. De wetenschappelijke zegslieden konden ook moeilijk anders. Want meer nog dan bij de extreem-laagfrequente elektromagnetische velden zijn de resultaten van wetenschappelijk onderzoek verwarrend.

Wel staat één effect goed vast: straling in het mega-en gigahertzgebied kan het lichaam opwarmen. Wordt die opwarming te groot - 1 graad celsius wordt a angehouden als veilige grens - dan is gezondheidsschade het gevolg. De niveaus bij mobiele telefonie zijn echter zodanig dat die veilige grenzen niet worden overschreden. ${ }^{35}$ ) 
De effecten waarover Coghill en Corney zich zorgen maken, zouden optreden bij blootstelling onder de grens voor opwarming. Ook de verontrusting over het optreden van hersen. tumoren bij frequente bellers of andere vormen van kanker bij omwonenden van antenne-installaties begint al bij blootstellingsniveaus ver onder de warmtegrens. De resultaten van onderzoek onder bevolkingsgroepen en in het laboratorium geven geen eenduidig beeld. Zo blijken wargenomen effecten afhankelijk te zijn van de frequentie die wordt gebruikt, van de eventuele modulatie en van de sterkte en de vorm van de velden. Het gebruikelijke toxicologische adagium: hoe meer blootstelling, hoe meer effect blijkt hier niet altijd op te gaan. In sommige situaties verdwijnt bij een grotere intensite it het effect weer.

Wat zeggen de deskundigenpanels? In 1997 concludeerde een commissie van de Gezondheidsraad over het gebruik van mobiele telefoons: ${ }^{36)}$

[...] dat de beschikbare wetenschappelijke gegevens er niet op duiden dat de absorptie van stralingsenergie afkomstig van [...] draagbare tellefoons, een gevaar oplevert voor de gezondheid, mits deze apparatuur op een normale wijze gebruikt wordt. Zij wijst er echter op dat er slechts zeer weinig gegevens over de energieabsorptie zijn.

In het advies zegt de commissie uitdrukkelijk dat het epidemiologische onderzoek geen aanwijzing heeft gegeven voor het optreden van kanker. Ze beveelt veilige maxima voor de blootstelling aan die zijn gebaseerd op opwarming.

In maart 1999 publiceerde het Canadese Koninklijke Genoot. schap een rapport over draadloze telecommunicatie en gezondheid. Het panel dat het rapport schreef, meldde in de samenvatting: 37 )

Het blijkt dat de blootstelling van de bevolking via de antennes van mobiele-telefoonnetwerken zo laag is, dat biologische effecten of effecten die nadelig zijn voor de gezondheid niet te verwachten zijn. Het gebruik van apparatuur voor draadloze telecommunicatie, zoals mobiele telefoons, kunnen mogelijk leiden tot een zodanig hoge blootstelling dat biologische effecten optreden, maar deze effecten zijn op grond van de huidige kennis geen voorbode van nadelige effecten op de gezondheid. [...] Het epidemiologische onderzoek geeft geen steun, ook gegeven de 
tekortkomingen wan het nu beschikbare onderzoek, aan de stelling dat blootstelling a an radiofrequente velden van draadloze-telecommunicatieapparatuur de ontwikkeling van tumoren bevordert. [...] Blootstelling aan radiofrequente velden zou het in slaap geraken kunnen wersnellen, maar dat wordt niet als nadelig voor de gezondheid beschouwd."

In grote lijnen spoort het recentere Canadese oordeel met dat van de Gezondheidsraad. Wel formuleren de Canadezen hun conclusies omzichtiger. Dat de elektromagnetische straling van de telefoons van invloed is op de biologische processen in het lichaam, staat woor hen vast. $Z i j$ vinden echter in de onderzoeksgegevens geen grond om die gevolgen als nadelig voor de gezondheid te bestempelen.

De mobiele telefonie heeft ook indirect invloed op de gezondheid. In de eerste plaats voor pacemakerdragers. Vooral de oudere typen pacemakers kunnen door tellefoonstraling worden gestoord. De Gezondheidsraadcommissie van 1997 beval daarom aan de mobiele tellefoon op ten minste $15 \mathrm{~cm}$ van de pacemaker te houden (dus niet in het verkeerde borstzakje te dragen). ${ }^{36}$ )

Mobiel telefoneren tijdens het autorijden vergroot de kans op verkeersongevallen. Uit onderzoek van het federale ministerie van vervoer in de VS volgt: ${ }^{38}$ )

[...] dat onoplettendheid en afgeleid zijn door het gebruik van een mobiele telefoon, net als andere vormen van afleiding, de kans op een autoongeluk doet toenemen. [...] Vooral het woeren wan het gesprek blijkt daar debet aan te zijn. Het is echter niet mogelijk op grond van de

It appears that exposure of the public to RF fields emitted from wireless telecommunication base station transmitters is of sufficiently low intensity that biological or adverse health effects are not anticipated. It is possible that users of wireless telecommunication devices, including cell phones, may experience exposures of sufficient intensity to cause biological effects, although these biological effects are not known to be associated with adverse health effects. (...) The level of evidence, and the limitations of the studies to date, do mot support a conclusion that exposure to RF fields of the type and intensity produced by wireless telecommunication devices contributes to the development of tumours. (...) RF field exposures may shorten the time to sleep onset in humans, although this biological effect is not considered an adverse health effect. 
beschikbare gegevens de omvang van het veiligheidsrisico door het gebruik van mobiele telefoons tijdens het rijden te schatten."

Het Nederlandse ministerie van verkeer en waterstat is een campagne begonnen om hands-free bellen in de auto te bevorderen, wanuit de gedachte dat vooral het intoetsen van het nummer en met éen hand de auto besturen belangrijke risicofactoren zijn. Daar zijn inderdaad aanwijzingen voor 399 , hoewel ander onderzoek geen steun biedt aan de gedachte dat hands free bellen veiliger is ${ }^{40)}$. Hoe dat ook zij, mobiel bellen tijdens het besturen van een auto lijkt een veiligheidsrisico te zijn, zij het dat de telefoon ma de klap kan zorgen voor het snel ter plaatse zijn van ' 112 '.

Als de elektromagnetische straling wan het telefoniesysteem een gezondheidsrisico vormt dan gellt dat vooral voor de bellers en veel minder voor de omwonenden van antenne-installaties, tenzij er bij hele lage niveaus subtiele, cumulatieve effecten zouden zijn, dat wil zeggen effecten die geleidelijk toenemen met de blootstellingsduur. Daarvan is echter in onderzoek niets gebleken.

Waarom dan toch die a anhoudende stroom berichten over klachten ten gevolge van antenne-installaties? Bewoners van tehuizen of huurflats hebben, formeel, niets te zeggen over de plaatsing van een antenne. Dat is een zaak van de telefoonmaatschappij, de eigenaar en mogelijk de overheid, voor zover voor het plaatsen van de antenne-installatie een vergunning nodig is. 41) Maar uit veel literatuur over risicovraagstukken is bekend dat het verstandiger is om de mensen die het in de praktijk aangaat, tijdig bij veranderingen in hun leefomgeving - hier het plaatsen van een antenne-installatie - te betrekken. ${ }^{3}$, 8) Want anders kunnen mensen bestaande klachten aan de onbekende eigenschappen van de antenne-installatie toeschrijven en kunnen

[... It can be concluded that in some cases, the inattention and distraction created by the use of a cellular telephone while driving is similar to that associated with other distractions in increasing crash risk. [...] Among these, conversation appears to be most associated with the crashes reviewed. Furthermore, it is clear that at this time there are insufficient data to indicate the magnitude of any safety-related problem associated with cellular telephone use while driving. 




die klachten verergeren. Het feit dat deskundigen het of niet weten, dan wel elkarar tegenspreken en het breed uitmeten daarvan in de media versterkt dat. Net als tijdens de Cola-affaire, kostte het enige tijd voor de aanbieders van mobiele telefonie en de overheid de klachten serieus gingen nemen. In Nederland is nu een informatietelefoon geopend van de gezamenlijke aanbieders, terwijl een Internet-pagina* in ontwikkeling is.

Figuur 9 geeft schematisch de risico-analyse van de mobiele telefonie weer. Afgezien van de risico"s die samenhangen met een verlies a an vertrouwen in overheden en telefoona anbieders en verkeersongevallen, lijken de risico's aardig onder controle. Totdat over ongeveer vijf jaar alle oude pacemakers door nieuwe zijn vervangen is het mogelijk door gedragsvoorschriften het risico voor de pacemaker-drager tot praktisch nihil reduceren. Aan het schema van figuur 9 zou men nog kunnen toevoegen: ergernis door mobiel gebel van anderen in openbare gelegenheden. Die ergemis kan bijdragen aan de onrust rond de platsing van antenne-installaties, maar gegevens daarover ontbreken.

hte.//www.monet-infonl/

Verspraate onder hoogspanning, 12 november 1999 
Ook voor mobiele telefonie heb ik een "balletjes"-risicokarakteristiek opgesteld (figuur 10). Gezien de relatief korte tijd dat mobiele telefonie gangbar is en rekening houdend met de explosieve groei wereldwijd, is de onzekerheid over de gevolgen door mij als hoger gewaardeerd dan in het geval van de elektriciteitsvoorziening.

\begin{tabular}{|c|c|c|c|c|c|}
\hline & $\begin{array}{c}\text { bewijs } \\
\text { epidemiologie }\end{array}$ & $\begin{array}{c}\text { kennus } \\
\text { mechanisme }\end{array}$ & $\begin{array}{l}\text { onzekerheid } \\
\text { gevolgen }\end{array}$ & $\begin{array}{l}\text { antral } \\
\text { getrofenen }\end{array}$ & $\begin{array}{l}\text { magelijkheid } \\
\text { madretrgelen }\end{array}$ \\
\hline $\begin{array}{l}\text { gerondheid, } \\
\text { woning }\end{array}$ & $0 \times$ & $\times 0$ & 00 & aro & $-x$ \\
\hline $\begin{array}{c}\text { gezondheid, } \\
\text { beller }\end{array}$ & 000 & $1 \times 0$ & 6. & & \\
\hline $\begin{array}{l}\text { indirecte } \\
\text { effecten }\end{array}$ & 60 & & $6 \times$ & ate & $(x)$ \\
\hline $0 \times 0$ & $\begin{array}{l}\text { chaos } \\
\text { bepertt } \\
\text { voldonde }\end{array}$ & $\begin{array}{l}\text { chats } \\
\text { bepertet } \\
\text { godi }\end{array}$ & $\begin{array}{l}\text { gerng } \\
\text { sanzientigk } \\
\text { groot }\end{array}$ & $\begin{array}{l}\text { erkeling } \\
\text { groepen } \\
\text { velen }\end{array}$ & $\begin{array}{l}\text { ecmowdig } \\
\text { dastig } \\
\text { onmogelink }\end{array}$ \\
\hline
\end{tabular}

Figuur 10 Karakteristiek van de risico's verbonden met de mobiele telefonie. 'Gezondheid, woning' heeft betrekking op blootstelling aan straling van de antenne-installaties, 'indirecte effecter' op de invloed op pacemakers en verkeersongevallen. 


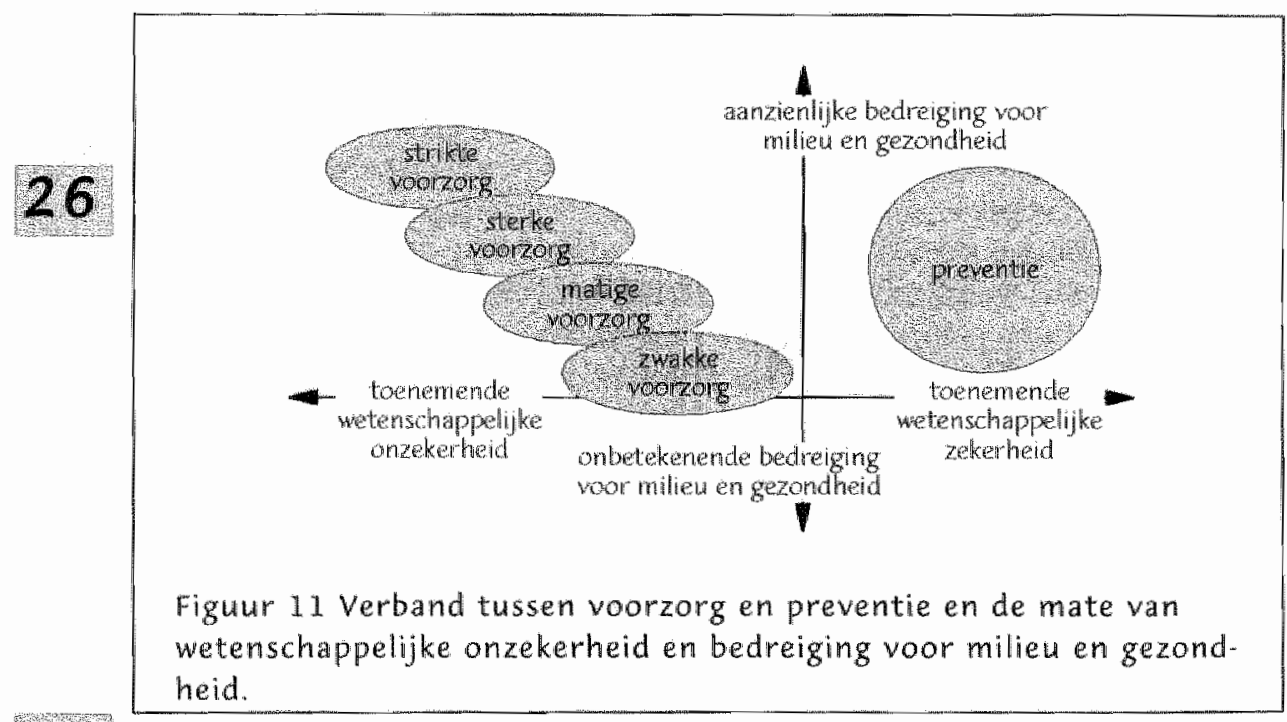

Verspraak onder hoogspanning, 12 november 1999 


\section{Wikken, wegen, voorzorgen en bestissen}

$R$ eijnders haalt in zijn intreerede bij de Open Universiteit de weigering van de gemeente Apeldoorn aan om vergunning te verlenen voor een radiozendmast. ${ }^{42)}$ Daarmee wil hij aantonen dat de conclusie van de Gezondheidsraad in 1997 dat grenswaarden voor veilige blootstelling aan radiofrequente straling slechts op grond van thermische effecten kunnen worden gesteld, niet de enig mogelijke is. ${ }^{43)}$ Door toepassing van het voorzorgprincipe valt er volgens hem een andere conclusie te trekken. Daarbij spelen dan overwegingen van mogelijk onherstelbare gezondheidsschade en het belang van de activiteit voor de samenleving een rol. Charnley, voorzitter van de Society for Risk Analysis, heeft een volstrekt andere visie. Volgens haar is in een wetenschappelijke risico-analyse geen plaats voor het voorzorgprincipe en zij wijst toepassing van dat principe dan ook onomwonden af." Daarbij heeft ze de Amerikaanse Kamer van Koophandel in Europa aan haar zijde, die in het voorzorgprincipe een stap naar politisering van de wetenschap ziet, naast een vrijbrief voor Europees protectionisme. ${ }^{44)}$

Volgens mij creëren zowel Reijnders als de Amerikanen onnodige en onwenselijke tegenstellingen. Van risico-analisten mag worden verwacht dat zij de wetenschappelijke gegevens over de risico's van de elektriciteitswoorziening en de mobiele telefonie zo goed mogelijk in kaart brengen "inclusief het ontbreken van informatie over die risico's. Dan begint een vertaalslag van die informatie naar de personen en instanties die verantwoordelijk zijn voor het nemen van beschermingsmaatregelen. In lijn met opvattingen die onlangs door anderen naar voren zijn ge-

Slotspeech van $\mathrm{G}$ Charnley tijdens het ge jaarcongres van de Society for Risk Analysis Europa te Rotterdam, 10-13 oktober, 1999.

wikken, wegen, voorzorgen en beshissen 
bracht 80,45$), 46), 47)$, inclusief de Gezondheidsraad 72,48 ), bepleit ik daarvoor 'samenspraak', dat wil zeggen geen één-maar een meerrichtingverkeer tussen de betrokken partijen. Tot die partijen behoren overheden, het bedrijfsleven, risicodeskundigen en, last but not least, burgers. De consequentie van die benadering is dat deskundigen - universitaire wetenschappers, onderzoeksinstituten en adviescolleges-, nadat ze hun analyses hebben uitgevoerd, nog steeds een rol te vervullen hebben. De weten. schappelijke informatie, de beleidsprincipes en de zorgen van de betrokkenen, kunnen tot nieuwe vragen leiden of tot andere accentem in de risico-analyse, uiteraard zonder de wetenschappelijke kwaliteit van de analyse geweld aan te doen.

Zowel in het elektriciteitsdebat, als in het telefoondebat wordt valk een tegenstelling gecreëerd tussen de 'voorzichtigen' en de 'ondernemenden', tussen de aanhangers en tegenstanders van het voorzorgprincipe. Ik acht die tegenstelling, zoals gezegd, onnodig en improductief. Te meer daar het 'voorzorgbeginsel', dat afkomstig is uit het Duitsland van de jaren ' $30^{49}$ ), als uitgangspunt voor het millieubeleid is vastgelegd in artikel 174.2 van het verdrag van de Europese Gemeenschap. ${ }^{50)}$ Het beginsel geldt dus ook in Nederland. In het kader van mijn betoog over 'hoogspanning' en 'verspraak' zijn twee aspecten van belang:49)

- voorkomen is beter dan genezen - het treffen van maatregelen ook al is het wetenschappelijk bewijs voor schade niet onomstotelijk geleverd

- evenredigheid maatregelen en kosten - de kosten van beschermingsmaatregelen of het afzien van bepaalde activiteiten moeten in redelijke verhouding staan tot de te verwachten effecten en de mate van onzekerheid daarvan.

Zowel voor de elektriciteitsvoorziening als voor de mobiele telefonie geldt dat er geen definitief bewijs is voor directe gezondheids. schade door blootstelling aan de opgewekte elektromagnetische velden of straling, maar slechts zwakke of uiterst zwakke vermoedens. Het "voorkomen is beter dan genezen"-aspect van het voorzorgprincipe houdt in dat dat geen reden is om de gezondheidsrisico's dan maar ter zijde te schuiven. De door mij voorgestelde 'balletjes-karakteristieken' leveren materiaal om te bepalen in welke mate doeltreffende en doelmatige matregelen op het voorzorgprincipe moeten worden gebaseerd. Zekerheid over de 
gevolgen leidt tot preventieve maatregelen; voorzorg speelt dan geen rol. 51) Naar mate echter de kennis gebrekkiger wordt en de mogelijke gevolgen ernstiger, komt voorzorg sterker in beeld. voor de elektriciteitsvoorziening kom ik dan op 'zwakke voorzorg' (figuur 11).

"Zwakke" toepassing van het voorzorgprincipe zou kunnen leiden tot het zovee! mogelijk scheiden wan woongebieden en hoogspanningslijnen, in elk geval bij de a anleg van nieuwe lijnen. Nader epidemiologisch onderzoek in Nederland lijkt weinig zinvol, zoals ook de Gezondheidsraad in 1992 concludeerde. Wel acht ik het nuttig dat onderzoek naar mogelijke mechanismen wordt gedaan. Dat is vooral van belang voor de invloed wan elektrische apparaten, waarvan de velden soms, althans vergeleken met die van de elektriciteitsdistributie, betrekkelijk hoog kunnem zijn, maar warover de kennis gering is. Feitelijk niet te handhaven gedragsvoorschriften, zoals het plaatsen de elektrische wekker ver van het bed, lijken me niet aangewezen, hoewel dat misschien wel het tijdig opstaan bevordert. veel beter acht ik het om te mikken op technologische vernieuwing mede in het kader van energiebesparing. De eerder genoemde 'samenspraak' tussen overheid, bedrijven, amalisten en burgers kan in zo'n aambeveling resulteren en vereist dan uitbreiding van de risico-analyse om de 'winst' van de energiebesparing in de effectbecijfering te betrekken.

Voor de mobiele telefoon acht ik op grond van het 'bolletjesprofiel' in figuur 10 meer aanleiding om uit voorzorg te handelen. Vooral de wereldwijde explosieve groei van het mobiel bellen noopt hier tot woorzichtigheid, gevoegd bij de bevinding dat, althans bij de bellers, sprake kan zijn van biologische effecten ten gevolge van de elektromagnetische straling.

Wat betreft het plaatsen van antenne-installaties gaat het voorall om goed overleg met alle partijen en woorlichting aan bewoners. Gevoegd bij een duidelijk, politiek gedragen beleid vergelijk Harlemmermeer ${ }^{52}$ ) _ zal dat naar mijn verwachting leiden tot het afnemen van klachten.

Onderzoek naar de gevolgen van draadloze communicatie voor de gezondheid verdient prioriteit om van mogelijk te veel of te weinig matregelen uit voorzorg te komen tot op kennis gestoel. de preventieve matregelen. 51 ) In feite gat het hier om een vorm van technologische-aspectenonderzoek (technology assessment)

wikkem, wegen, voorzorgen en beshssen 
dat de introductie van nieuwe technologieen op grote schaal standaard zou moeten vergezellen. Als onderdeel hiervan is zowel mechanistisch, als epidemiologisch onderzoek van belang; het epiderniologisch onderzoek onder bellers is immers nog nauwelijks van de grond gekomen. Van het ambitieuze programma van Wireless Technology Research ${ }^{53)}$, dat werd gefinancierd door de telecommunicatie-industrie in de VS, is weinig terecht gekomen. In de open literatuur is slechts gemeld dat mensen die met mobieltjes bellen geen ander sterftepatroon vertonen dan mensen die bellen met draadloze apparatuur waarbij de antenne niet bij het hoofd is. ${ }^{54}$ )

De indirecte effecten, zoals ongevalien door bellen in de auto, de verstoring van pacemakers en sociale verstoring door bellen in openbare ruimten, behoeven beleidsmatig niet met het voorzorgprincipe worden te lijf gegaan. De effecten zijn bekend, al hoewel niet alle maatregelen om ze te bestrijden. Op dit terrein ligt ook een richting voor verdere ontwikkeling van de technologie, in het bijzonder van de telefoontoestellen. Het is mogelijk dat zowel de blootstelling aan de velden tot een minimum wordt beperkt als de verstoring van het sociale leven in de omgeving van de beller. Ook hier ligt een primaire taak voor de telecommunicatie-industrie. 


\section{Onderzoek en onderwÿs}

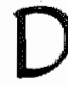

at brengt me dan bij mijn onderzoek, voor zover het me gegund is om me daar in mijn beperkte Maastrichtse tijd aan te wijden. Ik wil de nadruk leggen op de verruiming van de risicobeoordeling van een simpele benadering van 'mens wordt ziek van giftige stof of straling' tot een vorm van risico-karakterisering die een zinvolle rol kan spelen bij de consultatie en besluitvorming over beleidsmaatregelen ter bescherming van de gezondheid van mens en milieu. Daar hoort de analyse van de mate en gevolgen van blootstelling aan straling en stoffen bij, een gebied waarop onze Capaciteitsgroep Gezondheidsrisico-analyse en Toxicologie een ruime expertise heeft opgebouwd. Maar, zoals de 'verspraak'- en 'hoogspanning'-voorbeelden laten zien, spelen in de praktijk van alledag veel andere factoren een rol. Verder wil ik aandacht schenken aan methoden om kennis te waarderen en inzichtelijk te presenteren. Binnen de capaciteitsgroep ligt daarbij samenwerking met Harma Albering voor de hand. Ons gezamenlijke werk aan het Gezondheidsraadadvies over grote luchthavens vormde wat dat betreft een veelbelovende start.

Ook elders binnen de Universiteit Maastricht zie ik mogelijkheden voor samenwerking bij het door mij voorgestane onderzoek. De eerste contacten daartoe zijn reeds gelegd.

In het onderwijs milieugezondheidkunde kan de geschetste benadering van de risico-analyse zijn vruchten afwerpen. De afgestudeerden komen immers vaak op posities terecht waarin ze wetenschappelijke gegevens moeten verzamelen, interpreteren en aanreiken aan beleidsmakers. Om dienstig te zijn a an een goed beleid is een brede kijk op risicobeoordeling noodzakelijk. Zowel het door mij gecoordineerde onderwijsblok 'Milieu en Maatschappij' als de stagebegeleiding bood het afgelopen jaar gelegentheid die zienswijze over te brengen. 


\section{Dankwoord}

$A$ an het slot van dit betoog wil ik graag de stichting wetenuniversiteit en het bestuur van de Faculteit der Gezondheids. wetenschappen bedanken voor het in mij gestelde vertrouwen. Ik hoop dat vertrouwen niet te beschamen en deze bijzondere leerstoel 'risico-analyse' naar behoren te vervullen. De leden van de capaciteitsgroep Gezondheidsrisico-analyse en Toxicologie namen mij vorig jaar opgewekt in hun midden op en lieten mij mijn gang gaan. Een eervolle vermelding verdient Marie-Claire van der voort die zorgdroeg dat een calvinistische westerling in het Bourgondische zuiden, zowel in als buiten de universiteit, zijn draai en slaapplaats kon vinden.

Ik ben de Gezondheidsraad, met name in de persoon van de huidige voorzitter Jan Sixma, de voormalige voorzitter Leendert Ginjaar en algemeen secretaris Menno van Leeuwen, erkentelijk voor de bereidheid mij werk aan een academie te laten doen. Ook bij mijn afwezigheid bleven de medewerkers van de raad, in het bijzonder de aan mijn leiding toevertrouwde stafleden, gewoon doorwerken. Dat heeft mij het nodige over leiding geven geleerd.

Dank zij e-mail en mobiele telefoons is de mens steeds minder afhankelijk geworden van zijn geografische werkplek. Maar mensen blijven nodig om de communicatiekanalen te open houden en te verbinden. Bij de Gezondheidsraad vervult Marja van Kan die voor mij essentiële rol op voortreffelijke en vooral vriendschappelijke wijze.

Ik wil in het bijzonder Leendert Ginjaar bedanken die mijn verbintenis vanuit de Gezondheidsraad met de UM sterk heeft gestimuleerd en mij bovendien trachtte duidelijk te maken dat het ook 25 jaar na het verlaten van de universiteit bevredigend kan zijn in de schoot van de alma mater terug te keren. Na één jaar Maastricht kan ik zeggen: hij had het bij het rechte eind. 
De afstand Mastricht. Masland makt dat ik veel niet thuis ben. Door gepast gebruik van draderige en draadloze communicatie blijft de relatie tussen Willy en mij ook dan in stand. Mar het voorzorgprincipe geeft aanleiding matregelen te nemen om het nuttige in de komende tijd nog meer met het aangename te verenigen, omdat een relatie tussen mensen nu eenmal zeer veel meer inhoudt is dan risico of geluidklussen. Limburg biedt ook op dat purt mogelijkheden.

Ik hel gezegd. 


\section{Literatuur}

1 Hays CL, Cowell A, Whitney CR. How Coke Stumbled in Handling European Contamination Scare. New rork Times 1999 Jun 30.

2 NAS/NRC Committee. Risk assessment in the federal government: managing the process. Washington, DC: National Academy Press, 1983.

3 Statement of the Coca-Cola Company regarding quality issues in Belgium. Atlanta: The Coca-Cola Company, 1999. Internet: http:// www. the coca-colacompany.com/news/index.html, geraadpleegd 20-9. 1999.

4 Nemery B, Fischler B, Boogaerts M, Lison D. Dioxins, Coca Cola, and mass sociogenic illiness in Belgium [letter]. Lancet 1999; 354(9172).

5 Coke adds life, but cannot always explain it [editorial]. Lancet 1999; $354(9174)$.

6 van Loock F, Gallay A, Demarest S, v.d.Heyden J, wan Oyen H. Outbreak of Coca-Cola-related illness in Belgium: a true association [letter]. Lancet 1999; 354(9179).

7 Gezondheidsraad: Commissie Risicomaten en risicobeoordeling. Risico, meer dan een getal. Den Haag: Gezondheidsraad, 1996; nr 1996/03.

8 NAS/NRC Committee on Risk Characterization. Understanding Risk. Informing Decisions in a Democratic Society. Washington, DC: National Academy Press, 1996.

9 The Coca-Cola Company announces expectations for third quarter results and provides un update on business conditions. Atlanta: The Coca-Cola Company, 1999. Internet: http://www. thecocacolacompany.com/news/index.html, geraadpleegd 20-9-1999.

10The The Coca-Cola Company announces second quarter volume and earnings per share results. Atlanta: The Coca-Cola Company, 1999. Internet: http://www.thecoca-colacompany.com/news/index.html, geraadpleegd 20-9.1999

11 Steetskamp I, wan Wijk A. Stroomloos. Kwetsbaarheid van de samenle. ving; gevolgen wan de verstoringen van de elektriciteitsvoorziening. Den Haag: Rathenau Instituut, 1994. 
12 Grote Winkler Prins Encyclopedie. 7 de editie ed. Amsterdam: Elsevier, 1980 .

130ougle PG, editor. Energie Verslag Nederland 1998. Petten: ECN, 1999. 14.Elektriciteit in Nederland 1970, 1971, .., 1998. Arnhem: SEP en

EnergieNed, 1971-1999.

15 Brodeur $P$. Annals of radiation. The hazards of electromagnetic fields.

1-Power lines. The New Vorker 1989; (12 Jume): $51-88$.

16 Marino AA. Powerline electromagnetic fields and human health. 1999.

Internet: http://www.ortho.lsumcedu/Faculty/Marino/Powerline/

PowerlinetoC.html, geradpleegd 11-9-1999.

17 Weart S. Fears, Fantasies and Fallout [Symposium on Perception of

Risk and the Future of Nuclear Power: Confronting the Crisis of Public

Confidence in Science and Technology, 14 April 1993, Washington DC].

Physics and Society 1994;23(1).

18 Wertheimer $N$, Leeper E. Electrical wiring configurations and childhood

cancer. Am J Epidemiol 2979; 109(3):273-284

19 Savitz DA, Wachtel $H$, Barnes FA, John EM, Trrdik JG. Case-control

study of childhood cancer and exposure to $60 \mathrm{~Hz}$ magnetic fields. Am J

Epidemiol 1988;128(1): 21-38.

20 McBride ML, Gallagher RP, Theriault $G$ et al. Power-frequency electric and magnetic fields and risk of childhood leukemia in Canada. Am J

Epidemiol 1999; 149(9): 831-842.

21 Green $L M$, Miller $A B$, Villemeuve PJ et al. A case-control study of childhood leukemia in sowthern Ontario, Canada, and exposure to magnetic fields in residences. Int J Cancer 1999; 82(2): 161-170.

22 Hafemeister D. Background paper on 'power line fields and public health'. 1996. Internet: http://www.calpoly.edu/ dhafemei/

background2.html, geraadpleegd 25-9-1999.

23 Marino AA. EMF bioeffects debate results from a paradigmatic shift Presented at the Bioelectromagnetics Saciety 18 th Annual Meeting. June 14, 1996, Victoria, British Columbia, Canada]. 1996. Internet: http:/www,ortho.lsumc.edu/Faculty/Marino/BEMS.html, geraadpleegd 27-9-1999.

24.Gezondheidsraad: Commissie. ELF elektromagnetische velden. Extreem laagfrequente elektromagnetische velden en gezondheid. Den Haag: Gezondheidsraad, 1992; nr 1992/07.

25 NAS/NRC Committee on the Possible Effects of Electromagnetic Fields on Biologic Systems. Possible Health Effects of Exposure to Residential Electric and Magnetic Fields. Washington DC: National Academy Press, 1997. Internet: http://Www.nap.edu/catalog/5155.html. 
260 lden $K$. Health Effects from Exposure to Power Line Frequency Electric and Magnetic Fields. Prepared in Response to the 1992 Energy Policy Act (PL 102-486, Section 2118). Research Triangle Park, NC. USA: NIEHS, 1999; NIH Publication No. 99-4493. Internet: http:// www niehs.nih.gow/emfrapid/htm//EMF_DIR_RPT/NIEHS_Report.pdf. 27 Ulrich RS. Biophilia. biophobia and naturall landscapes. In: Kellert $S R$, Wilson EO, editors. The biophilia hypothesis. Washington DC: Island Press/Shearwater Books, 1993: 73-137.

28 Hartig $T$, Böök A, Garvill J, Olsson T, Garling T. Environmental

influences on psychological restoration. Scand J Psychol 1996:37:

378-393.

29 simpson D. Cell time for using a cell phone. zDNet $1999 \mathrm{Jul} 21$.

Internet: http://www.zdnet,com/zdnn/stories/news/

$0,4586,2298512,00$.html.

30 Fleming AT. Ten strijde tegen de mobiele telefoon. NRC-Handelsblad $1999 \operatorname{Sep} 11$.

31 CTIA's Semi-Annual Wireless Survey. Washington, DC: Cellular Telecommunications Industry Association, 1999. Internet: http:// www.wow-com.com/wirelesssurvey/, geraadpleegd 21-9-1999.

32 Glasner J. Feds OK Cell Phone Tracking. Wired News 1999 Sep 16.

Internet: http://www.wired.com/news/print_version/email/explodeinfobeat/business/story/21781.html?wnpg=all.

33Are mobile phones a health hazard? BBC News Online 1999 Apr 8.

Internet: http://news.bbc.co.uk/low/english/health/newsid_314000/ 314363. stm.

34 Mabile caused brain damage, claims man. BBC News Online 1999 Mar 15. Internet: http://news.bbc.co.uk/low/english/health/ newsid_296000/296976.stm.

35 van Leeuwen GMJ, Lagendijk JJW, van Leersum BJAM, Zwamborn APM. Thermal ER RF Modelling of Cellular Phones (THERMIC). Work Package 2: Demonstration and validation of the models. Den Hag: TNO Physics and Electronics Laboratory, 1999; TNO report FEL-99-CI28.

36 Gezondheidsraad: Commissie kadiofrequente straling. Radiofrequente elektromagnetische velden $(300 \mathrm{~Hz}-300 \mathrm{GHz}) / R$ adiofrequency electromagnetic fields $(300 \mathrm{~Hz}-300 \mathrm{GHz}$ ). Den Hag: Gezondheidsraad, 1997; nr $1997 / 01$. 
$37 R S C$ Expert Panel on the Patential Health Risks of Radiofrequency Fields from Wireless Telecommunication Devices. A Review of the Potentiel Health Risks of Radiofrequency hields from Wireless Telecommunication Devices. An Expert Panel Report prepared at the request of The Royal Society of Canada for Health Canada. Ottawa, Ontario: Royal Society of Canada, 1999. Internet: http://www.rsc.cal english/RFreport.pdf.

38 Goodman M, Bents FD, Tijerina L, Wierwille $W$, Lerner $N$, Benel D. An Investigation of the Safety Implications of Wireless Communications in Vehicles. U.S. Department of Transportation, National Highway Traffic Safety Administration, 1998; Contract DTNH22-92-0-07002. Internet: http://www.nhtsa.dot.gov/people/injury/research/wireless/index.html. 39 Brookhuis $K A$, de Vries $G$, de Waard $D$. The effects of mobile

telephoning on driving performance. Accid Anal Prev 1991; 23(4): 309.31.6.

40Redelmeier DA, Tibshirani RJ. Association between cellular-telephone calls and motor vehicle collisions. N Engl J Med 1997; $336(7)$ : 453. 458.

41 Informatie over antenne-installaries voor mobiele telecommunicatie. Voor overheden en operators. Den Haag: Ministerie van Verkeer en Waterstaat, Ministerie van Volkshuisvesting, Ruimtelijke Ordening en Milieubeheer "Ministerie van Sociale en Werkgelegenheid, Ministerie van Volksgezondheid, Welzijn en Sport, 1999.

$42 \mathrm{~B} E \mathrm{~W}$ Apeldoorn. Beslissing van het college van burgemeester en wethouders van Apeldoorn inzake het verzoek d.d. 28 februari 1997, ontvangen 4 maart 1997 wan Delta Radio 171 B.V. om een vergunning. ingevolge de Wet milieubeheer voor het oprichten en in werking hebben van een radiozendstation, gevestigd op het perceel Radioweg I te Radio Kootwijk (Gemeente Apeldoorn). Beschikking 97 WM 608. 261-1998. Internet: http://www apeldoorn.nl, geraadpleegd 21-5-1999 43 Reijnders L. Naar een duurzamere technologische ontwikkeling. Open Universiteit, 1999; Oratie.

4.4EL Committee Position Paper on a Comprehensive Risk Analysis Process. Brussel: The EU Committee of the American Chamber of Commerce, 1999. Internet: http://www eucommittee.be/Pages/ fspop.htm, geraadpleegd 16-10-1999.

45Commission on Risk Assessment and Risk Management. Framework for environmental health risk assessment. Volume 1. Washington DC: The Presidential/Congressional Commission on Environmental Health Risk Assessment, 1997; Final Report. 
46. Commission on Risk Assessment and Risk Management. Risk assessment and risk management in regulatory decision making. Volume 2. Was. hington DC: The Presidential/Congressional Commission on Environmental Health Risk Assessment, 1997; Final Report.

47Dubrewil H, editor. The TRUSTNET Framework: A New Perspective on Risk Governance. Paris, France: Mutadis, 1999; Final Report EU Trustnet Concerted Action.

48 Health Council of the Netherlands: Committee on the Health Impact of Large Airports. Public health impact of large airports [Grote luchtha. vens en gezondheid]. The Hague: Health Council of the Netherlands, 1999; $\mathrm{mr} 1999 / 14 \mathrm{E}$.

490 'Riordan $T$, Cameron J, editors. Interpreting the precautionary principle. London: Earthscan Publications Ltd, 1994. 50 Verdrag tot oprichting van de Europese Gemeenschap [25 maart 1957; Verdrag wan Rome]. Geconsolideerde versie. Luxemburg: Bureau voor officiële publicaties der Europese Gemeenschappen. 1997.

51.Deville $A$, Harding R. Applying the precautionary principle. Sydney: The Federation Press, 1997.

$52 \mathrm{BEW}$ Haarlemermeer. Informatie over GSM-zendinstaliaties, $23 \mathrm{fe}$ bruari 1999, nota GSM-installaties. 1999. Internet. http:// www.haarlemmermeer.nl/gsm/gsm_bel/nota.html, geraadpleegd 27.9. 1999.

53 Wireless Technology Research, LLC. Endorsed, Peer-Reviewed Epidemiology Studies. Washington, DC: Wireless Technology Research, LLC, 1997.

54 Rothman KJ, Loughlin JE, Funch DP, Dreyer NA. Overall mortality of cellular telephone customers [see comments]. Epidemiology 1996; $7(3): 303-305$. 